\title{
Investigating the Impress of the Active Tectonics and the Rate of Fractures in Ilam Formation, Fars Area, SW Iran
}

\author{
Reza Poursoltani ${ }^{*}$, Mohsen Pourkermani1 ${ }^{1}$, Koros Yazdjerdi' ${ }^{2}$, Mahmood Almassian ${ }^{1}$ \\ ${ }^{1}$ Department of Geology, North Tehran Branch, Islamic Azad University, Tehran, Iran \\ ${ }^{2}$ Department of Geology, Shiraz Branch, Islamic Azad University, Shiraz, Iran \\ Email: *reza.poursoltani@gmail.com
}

Received 30 April 2016; accepted 26 June 2016; published 29 June 2016

Copyright (C) 2016 by authors and Scientific Research Publishing Inc.

This work is licensed under the Creative Commons Attribution International License (CC BY). http://creativecommons.org/licenses/by/4.0/

(c) (i) Open Access

\begin{abstract}
The evolution of the Active Tectonics of the Ilam Formation (Santonin) form potential reservoir rocks at oilfields and structures in costal fars. Core and cuttings samples and wire-line logs from wells in the East Gardan field were used to investigate microfacies types and porosity evolution. Facies modelling was applied to predict the relationship between facies distribution and reservoir characteristics to construct a predictive geologic model which will assist future exploration in East Gardan field. Microfacies analysis and electrofacies identification and correlations indicate that the limestones of the Ilam Formation were deposited in a ramp setting. The ramp developed over the distal margin of the Santonin proforeland basin, adjacent to the evolved forebulge. Inner ramp facies are characterized by carbonate bank bioclastic packstones. Middle ramp facies dominate the Ilam Formation and consist of bioturbated, massive, dolomitic and bioclastic limestones. Bioclasts include benthic and planktonic foraminifera. Intense less common Palaeophycus bioturbation has enhanced the porosity of this facies. Outer ramp deposits consist of alternating mid-ramp bioturbated bioclastic massive limestones and argillaceous and marly limestones. Bioclastic packstones and intensively bioturbated bioclastic limestones of the mid-outer ramp are the primary source of fabric-selective porosity which is greatly enhanced by diagenetic overprints.
\end{abstract}

\section{Keywords}

Zagros, Iran, Ilam Formation, Field, Carbonate Reservoir

\section{Introduction}

The associated foreland basin represents one of the oldest and richest hydrocarbon provinces known [1]. The

${ }^{*}$ Corresponding author.

How to cite this paper: Poursoltani, R., Pourkermani, M., Yazdjerdi, K. and Almassian, M. (2016) Investigating the Impress of the Active Tectonics and the Rate of Fractures in Ilam Formation, Fars Area, SW Iran. Open Journal of Geology, 6, 498515. http://dx.doi.org/10.4236/ojg.2016.66041 
fold-and-thrust belt formed as a result of Neogene convergence and suturing between the Arabian Plate and the Iranian block [2]. The Zagros Main Thrust and accompanying ophiolites form the northern margin of the belt and separate it from the Central Iran block. The deformation front of the Iranian part of the belt has an irregular geometry in map view, and is characterized by two major bulges, referred to as the Coastal Fars and Fars salient, separated by the Izeh Embayment (Figure 1). The Fars area has a long history of hydrocarbon exploration and production but relatively few wells drilled here have been successful. Both high quality source rocks and regional seals are present and carbonates in the Santonian Ilam Formation form a major reservoir unit although permeability varies significantly due to variations in depositional facies and diagenesis.

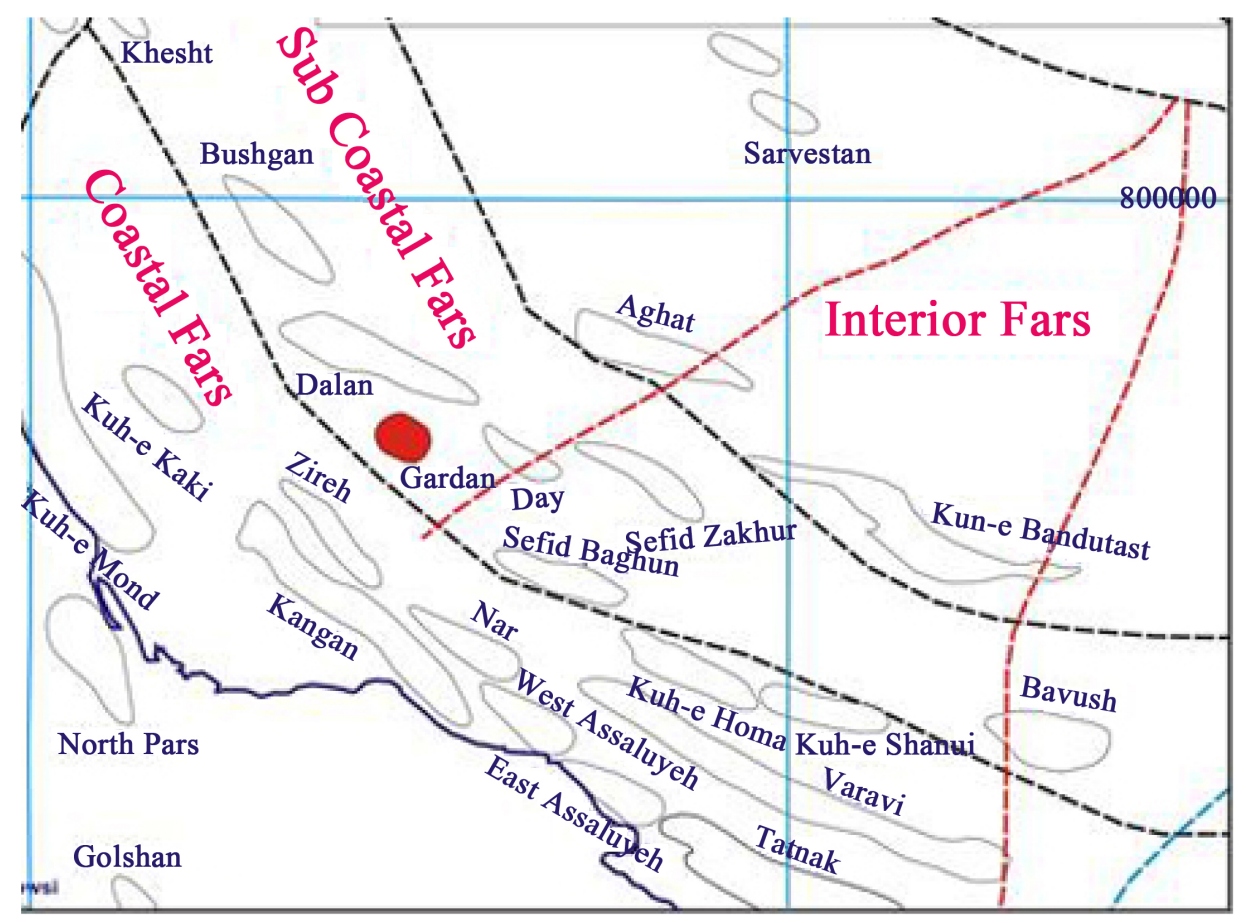

Figure 1. Location map of the Fars region with the main structural features and subdivisions of the Zagros fold-and-thrust belt.

\subsection{Location}

The numerous studies of the Zagros fold-and-thrust belt which have been made, relatively little has been published concerning the link between structural evolution and foreland basin development. Some authors [3] have suggested that basement faults had a significant effect on the geometry of the Zagros deformation front and the evolving foreland basin. Thickness and facies variations, as well as local and regional unconformities, have been related to the reactivation of basement faults or the migration of the foreland basin between Late Cretaceous ophiolite obduction and late Miocene collision [2] [4]. The major regional angular unconformity between the Aghajari Formation has previously been considered to mark the climax of the orogeny in the late Pliocene [5]. More recently, the beginning of Zagros deformation has been dated at different times before the late Pliocene [6] [7] based on various types of geological evidence and methodologies. As a result of its complex stratigraphy and the wide variations in sediment facies and thicknesses, the Fars area is an ideal location in which to study foreland basin development. This paper presents the results of a regional-scale study of basin evolution in the Fars salient (Figure 2), based on recent fieldwork, together with unpublished logged surface sections of the Late Cretaceous and the early Miocene. The objective was to investigate the effects of the Zagros orogeny and of basement fault activity on basin evolution in Fars.

\subsection{Geology Setting}

The separation of Arabia from Africa and its convergence with Eurasia was the last in a series of separation- 


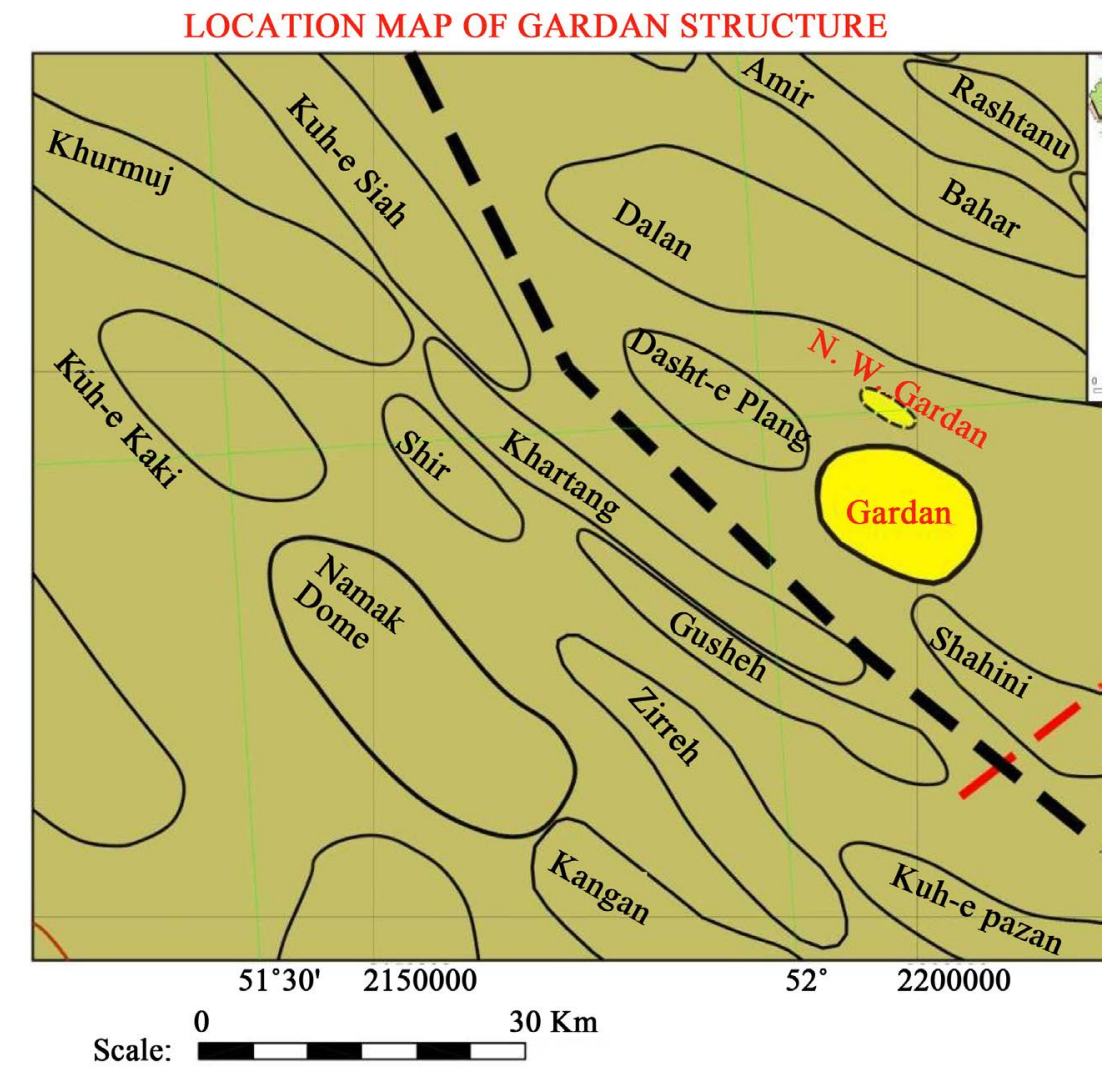

Figure 2. The location of field photographs (Figure 4 and Figure 5) is also shown. The proposed Nezam-Abad Fault is marked by dashed lines; note the sinuosity of the Gardan anticline.

collision events which gave rise to the Alpine-Himalayan orogenic system [8]. The Zagros fold-and-thrust belt, part of this system, is bounded to the NW by the East Anatolian left-lateral strike-slip fault and to the SE by the Oman line [9] [10] summarized the evolution of the Zagros orogeny in terms of three sequential phases: 1. Subduction of Neo-Tethyan oceanic crust beneath the Iranian lithospheric block during the Early to Late Cretaceous; 2. Emplacement (obduction) of ophiolite sheets derived from the Neo-Tethyan ocean floor over the Arabian continental margin in the Late Cretaceous (Turonian to Campanian) [2] suggested that the beginning of compressional deformation in the Zagros occurred during this time period, during the final closure of Neo-Tethys with the suturing of Arabia with Central Iran. 3. Collision of Afro-Arabian continental lithosphere with the Iranian plates during Late Cretaceous and later times. The growth of anticlines in the Holocene [11], together with recent seismicity, indicate that deformation in the fold-and-thrust belt is continuing, particularly at deep crustal levels [7]. Regional north-south convergence is taking place at rates which have been estimated at between 25 $30 \mathrm{~mm}$ per year [12] and 20 - $25 \mathrm{~mm}$ per year. The rate of convergence varies in different parts of the Zagros belt [13] and the convergence rate is less in Fars than in Fars to the east, based on an Arabia-Iran pole of rotation [14].

The Zagros fold-and-thrust belt can be divided into a number of zones which differ according to their structural style and sedimentary history [2]. In Fars, the belt is bounded in the NE by the Main Zagros Reverse Fault and Main Recent Fault (Figure 1). The Main Zagros Reverse Fault is thought to mark the suture zone between Arabia and Eurasia [8] and has been outlined by earthquake focal mechanism solutions [15]. This fault marks the southern boundary of the Sanandaj-Sirjan metamorphic belt. However, some authors [16] [17] have included the metamorphic rocks located to the NE of the Main Reverse Fault within the Zagros fold belt. The Main Recent Fault, a relatively recent, right-lateral fault, which is currently seismically active along a few segments [18], follows the trace of the Main Zagros Reverse Fault out of Turkey to approximately lat.32oS, the northern limit of Fars. To the SW, the High Zagros Zone (Figure 1) contains highly imbricated slices of sedimentary cover rocks 
and fragments of Cretaceous ophiolites [18]. This zone is up to $80 \mathrm{~km}$ wide and forms the topographically highest part of the Zagros [19]; it contains the oldest exposed rocks and is limited to the SW by segments of the High Zagros Fault. To the SE of the High Zagros zone is the Simply Folded Zone which includes the study area for this paper, and which is bounded to the SW by the Mountain Front [20] or the Mountain Front Fault [18] (Figure 1). The Zagros belt can also be divided by a series of transverse lineaments. The Bala Rud Fault (or line) separates eastern Fars from the Izeh Embaymen [4]. To the west, Fars is bounded by the Khaneqin fault which separates it from the Kirkuk Embayment (Figure 1).

\subsection{Zagros Foreland Basin}

Some 7 to $12 \mathrm{~km}$ of sediments were deposited in an epicontinental synorogenic foreland basin which developed in front of the evolving Zagros orogeny [10]. The sedimentary cover rests on Proterozoic metamorphic rocks of the pan-African basement, considered to be the NE continuation of the Arabian Shield which is exposed in the SW of the Arabian Plate. The only exposed basement rocks within the Zagros fold-and-thrust belt are blocks of metamorphic material brought to the surface in salt diapirs [5], but these are not present in Fars. North-south faults have controlled the facies and thickness of Phanerozoic sedimentary rocks, at least from the middle Cretaceous [20]. A thickness and facies pattern parallel to the developing Zagros (NW-SE trending orogeny) was gradually superimposed on the pre-existing north-south trending subsidence pattern after the Late Cretaceous. Authors have proposed that there are no major angular unconformities within the sedimentary column in the Zagros between the Lower Cambrian and the Pliocene. However, recent studies [4] have documented the occurrence of unconformities which are interpreted to reflect tectonic activity. Thickness variations of Miocene sediments across the Zagros belt are related to patterns of synorogenic sedimentation [4].

\subsection{Sedimentary Characteristics}

There are significant differences in sedimentary thickness and facies between Fars and the Izeh Embayment. For example, The Dalan Formation (limestones) and Dashtak Formation (anhydrites) in the Izeh Embayment pass into the Adaiyah Formation (evaporites), Mus Formation (carbonates), Alan Formation (evaporites), Sargelu Formation (shale and marls), Najmeh Formation (carbonates) and Gotnia Formation (evaporites) inFars. Similarly, Cretaceous sedimentary rocks of the Lower Khami Group, including the Fahlian, Gadvan and Darian Formations which mostly consists of neritic carbonates, pass into pelagic facies of the Garau Formation. Thickness and facies changes within the Santonian Ilam Formation have been documented in subsurface data and in the field. The Sarvak Formation, a Paleocene-Eocene limestone in the Izeh Embayment, passes into the Amiran Formation (marls, shales and sandstones), the Talehzang Formation (carbonates), the Kashkan Formation (conglomerate and sandstone) and the Shahbazan Formation (dolomite). A generalized lithologic and stratigraphic column for the study area, based on data from a variety of sources, is shown in (Figure 3). Data sources include the surface section in the NE of the study area for the Lower Palaeozoic; the Homawells for the Permian to Jurassic; (See Figure 2 for the location of the structures) for the Cretaceous; and a number of measured stratigraphic surface sections for the Upper Cretaceous to lower Miocene interval. These observations indicate significant thickness variations for most of these formations in the study area. However, average thicknesses for each formation are given in the chart of Figure 3.

\subsection{Foreland Basin History}

In order to investigate the evolution of the Zagros foreland basin in the study area between the mid-Cretaceous and the onset of Zagros folding, a number of isopach maps for time intervals between the Santonian and Miocene were prepared. These maps were constructed using re-evaluated logged sections originally prepared by, (Figure 1) together with available well data.

\section{Materials and Methods}

For the preparation of the isopach maps, the thickness of sedimentary rocks for each time interval was obtained from surface sections and well data. These values were then adjusted for the exact location of the data sources (surface section or well), and were contoured using minimum curvature equations.

Santonian sediments were studied in order to investigate the influence of pre-existing basement lineaments 


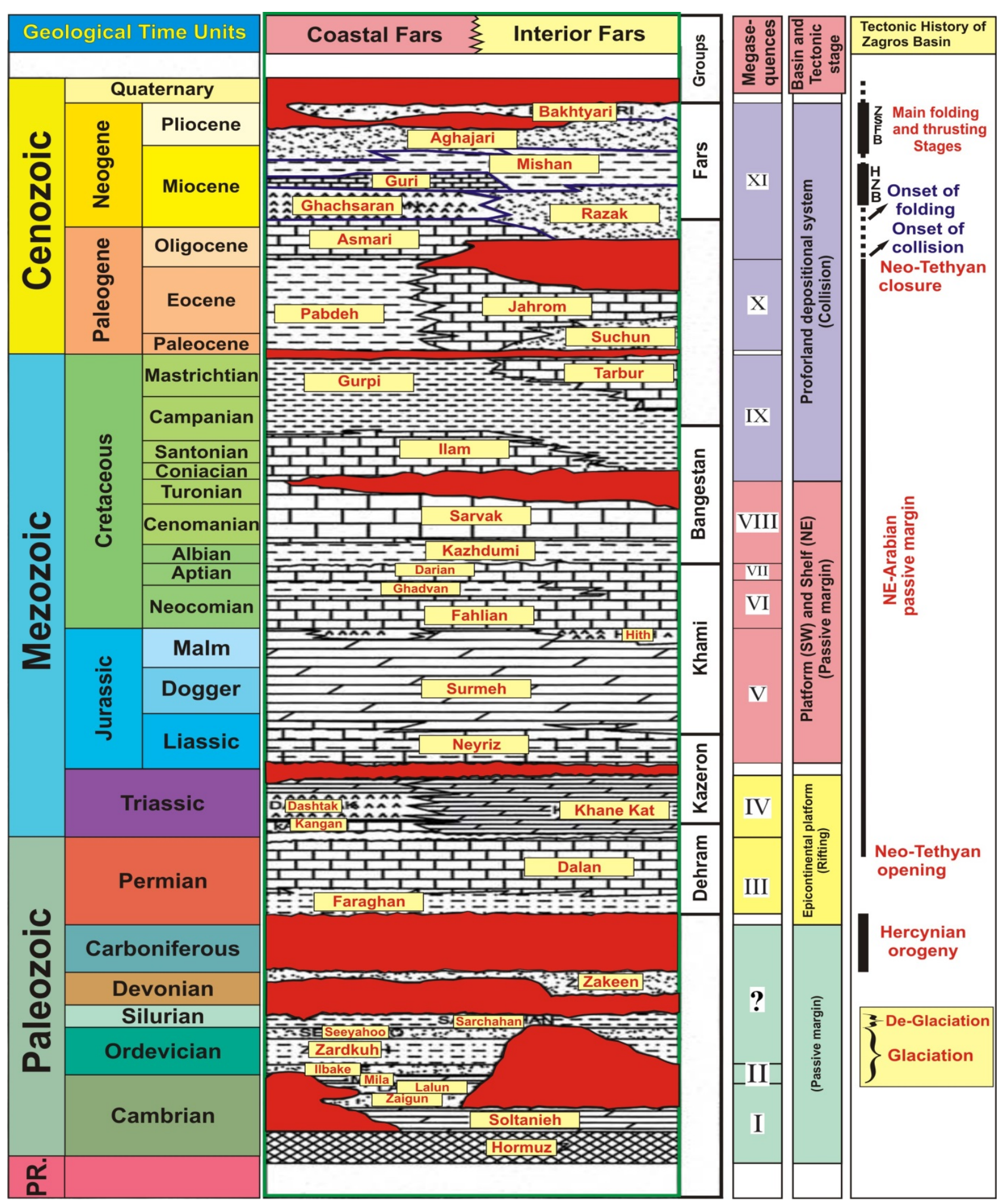

Figure 3. Stratigraphic chart for the Fars region based on measured surface sections, well data and field observations. Formation thicknesses vary throughout the study area, and average values are therefore given.

and Zagros folding (Santonian) on the evolution of the basin. The Santonian Ilam Formation is an important carbonate reservoir unit in Fars. Field observations show that the formation is composed of both neritic and pelagic 
facies in different parts of the study area. In the eastern part of the Homa anticline (Figure 2), the formation is dominated by pelagic facies (upper Santonian and Turonian) which overlie neritic facies (Santonian) (Figure 4). The pelagic facies locally follow the approximately north-south trend of the Gardan lineament, within which the axis of the Gardan anticline demonstrates marked sinuosity (Figure 2). Bedding within the Ilam Formation indicates a clinoform geometry in the Homa anticline (Figure 5). The presence of pelagic facies in the westernmost part of the Homa anticline and the presence of clinoform stratal patterns in carbonate intervals towards the WNW confirms the palaeo slope of the Ilam Basin from ESE to WNW in this part of the region (Figure 5). The isopach map for the Santonian (Figure 6) indicates thickness variations along roughly north-south (or NE-SW) trending anomalies. One of the north-south trending anomalies appears to be aligned with the Gardan lineament. This anomaly coincides with the eastern part of the Homa anticline, where pelagic facies in the Ilam Formation rest on neritic deposits. The thickness of Santonian sediments decreases towards the western and eastern margins of the trend (Figure 6). The Campanian-Maastrichtian isopach map (Figure 7) demonstrates thickness variations along a NW-SE trending anomaly parallel to the general trend of the Zagros fold-and-thrust belt. Northsouth trending anomalies (i.e. those at high angle to the Zagros belt, are absent from this isopach map. The heavy dashed line parallel to the Zagros trend is the best-fit line through the foreland basin depocentres. The Paleocene-Eocene isopach map is based on measured stratigraphic surface sections and well data. A number of NW-SE trending anomalies are apparent on the map. As with Figure 7, the heavy dashed line is the best-fit line through the foreland basin depocentres. Note that this line of this map is displaced SWwards compared to the Campanian-Maastrichtian isopach map (Figure 7), demonstrating SWwards migration of the foreland basin depocentre. Further SWwards migration of the depocentre is indicated on the isopach map, relative to the Albian isopach map. The map also shows a NW-SE trending isopach anomaly in the northern part of the study area, and a roughly north-south trending anomaly, aligned with the Gardan lineament, in the southern part. This change in tend is supported by field observations. In the north of the Gardan lineament, there is some evidence for the
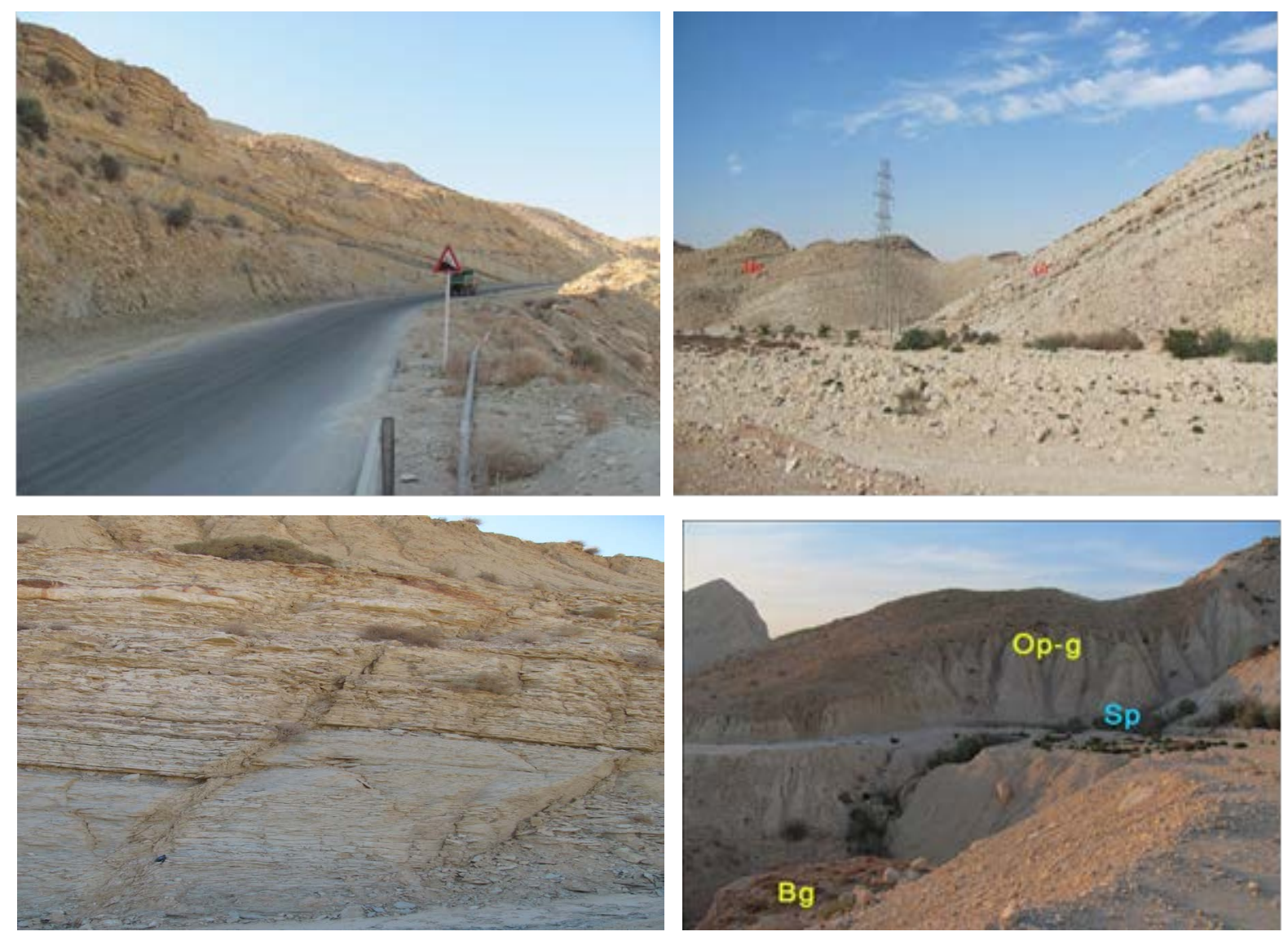

Figure 4. Field photographs from the eastern part of the Homa anticline (see Figure 2 for location). The photos show pelagic facies of the Santonian Ilam Formation overlying neritic facies. 

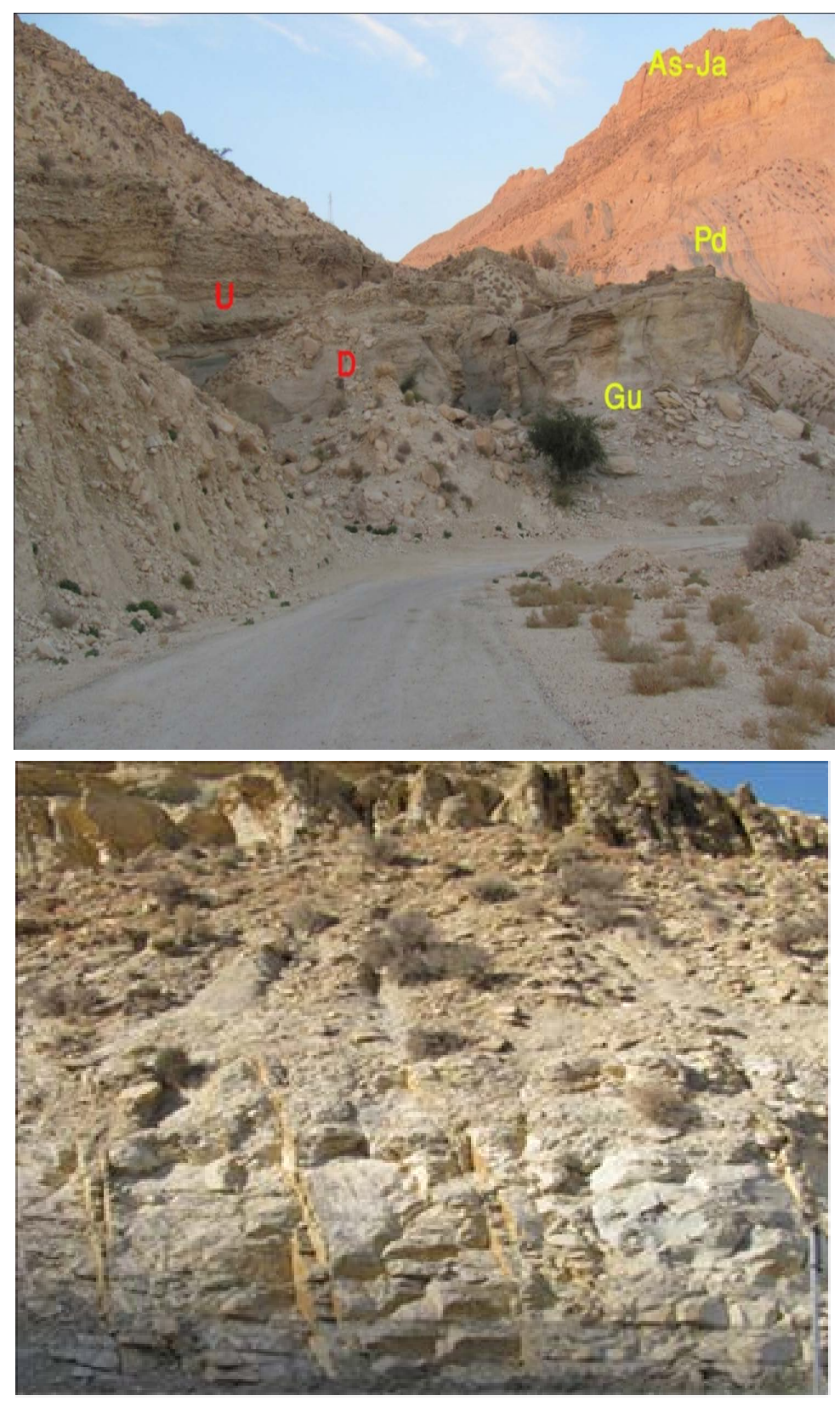

Figure 5. Field photographs from the core of the Homa anticline (see Figure 2 for location). The photographs show the clinoform stratal pattern within the, Asmari and Jahrom Formations indicating deepening of depositional conditions towards the NW along the Gardan lineament.

existence of a palaeohigh during deposition of the Santonian Ilam Formation carbonates. Thus Figure 8(a) shows an area close to the eastern plunge of the Saiwah anticline (location in Figure 2). The photo shows the progradation of Ilam Formation carbonates towards the deeper parts of the Ilam basin from west to east. Also, on the northern flank of the Saiwah anticline (Figure 8(b), location in Figure 2), reefal packages within the Ilam carbonates pass into thinner beds to the east, towards the deeper part of the Ilam basin. The western margin of the Gardan lineament at the northern limb of the Genu anticline, NW of Ilam City, is shown in Figure 8(c) (location on Figure 2). At this location, the progradational stratal pattern indicates deepening of the Ilam basin towards the west. Finally, a Bouguer anomaly map of the study area with a low-pass filter [21] (Figure 9) shows thickening of the sedimentary package from SW to NE, at high angle to the Zagros belt. 


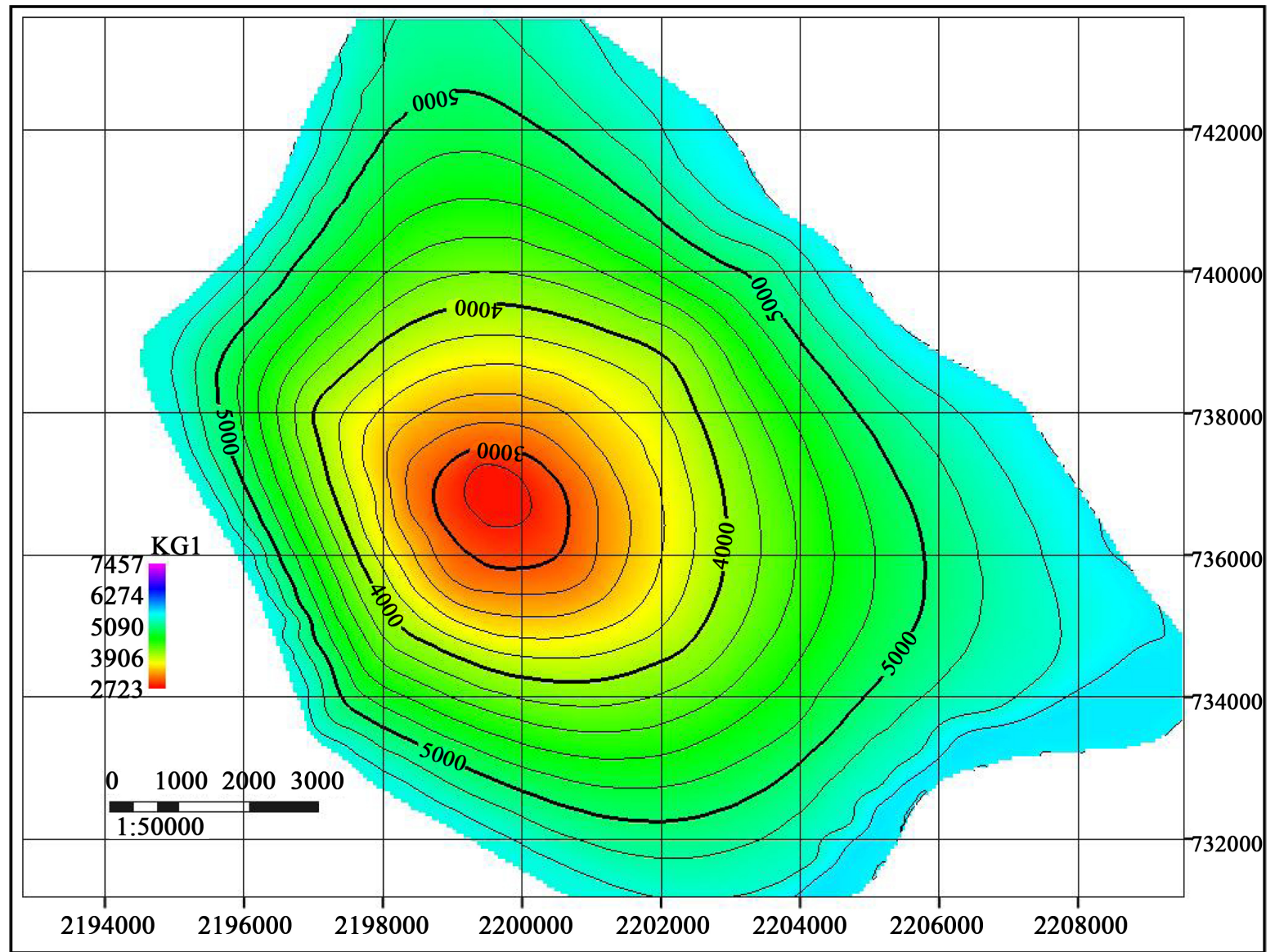

Figure 6. Isopach map of the Santonian interval in the Fars region based on logged surface sections together with fieldwork data and well data.

\section{Results and Discussion}

In Fars, both reactivation of basement faults and/or Zagros deformation controlled the evolution of the foreland basin between the Late Cretaceous Below, we discuss the isopach maps compiled in order to study the effect of these two elements on foreland basin evolution.

\subsection{The Effect of North-South Trending Basement Structure on Basin Characteristics}

Previous studies have drawn attention to the presence of north-south trending strike-slip faults in the basement of the Iranian Zagros [22] [23] The effects of some of the north-south structural trends in the basement can be recognized on Landsat images, for example from the sinuosity of the fold axes [24]. Thus, the sinuosity of the Gardan anticline in the southern part of the study area is attributed to offset on a basement lineament which can tentatively be followed into the northern flank of the Homa anticline, SE of Ilam City (Figure 10). As mentioned above this trend, which may be a reactivated north-south basement fault, is referred to here as the Gardan lineament. Phases of basement activity during the evolution of the Zagros basin have affected facies and thickness Both thickness changes in the Santonian isopach (Figure 6), and the change from neritic facies in the Santonian Ilam Formation to mostly pelagic facies elsewhere in the southern part of the study area, take place along the roughly north-south Gardan lineament (Figure 2). This suggests that this lineament or palaeohigh was active during deposition of Santonian Ilam Formation. After the mid-Cretaceous tectonic phase (post-Santonian), a series of highs aligned in general north-south, parallel to the Arabian trend, originated in the Izeh embayment area. documented the existence of several palaeohighs during deposition of Cretaceous Bangestan Group sediments along pre-existing basement lineaments in the Izeh Embayment. Other authors emphasized that transverse 


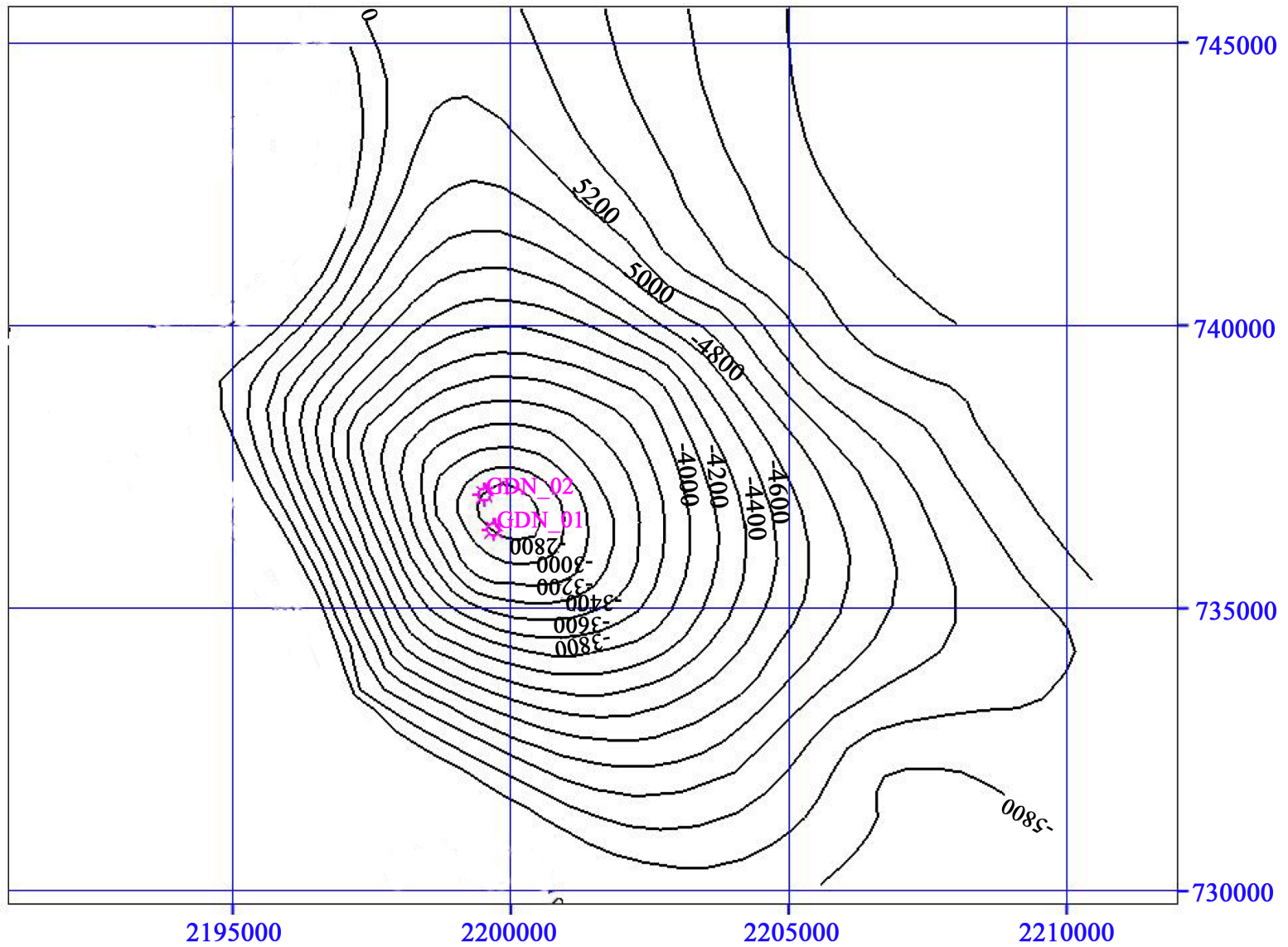

Figure 7. Isopach map of the Campanian-Maastrichtian interval. Contour interval is $100 \mathrm{~m}$. Isopach anomalies in general trend NW-SE, parallel to the axis of the Zagros belt.

strike-slip basement faults in the Zagros (i.e. Arabian trend faults) have controlled the facies and thickness of sediments deposited since at least the middle Cretaceous. The Kazerun and Hendijan-Bahregansar faults (Figure 1) correspond to a series of roughly north-south striking linear uplifts along pre-existing basement trends. Proposed that these trends were reactivated in response to ophiolite obduction in the Late Cretaceous, and may have influenced sedimentation. Based on seismic data and field observations at Izeh and in the Izeh Embayment documented thickness and facies variations in Albian-Santonian strata along the Hendijan-Bahregansar fault. It is suggested here that the Gardan lineament represents a roughly north-south striking, linear uplift along a pre-existing Arabian basement lineament which was reactivated in the Late Cretaceous (activation before the late Cretaceous is unknown), in response to the onset of the Zagros orogeny and ophiolite obduction. The effects of activity on the Gardan lineament on the evolution of the foreland basin appear to decrease both with time (as indicated by isopach maps: Figure 7) and in a northwards direction.This demonstrates that, from the Late Cretaceous to the present day, Zagros deformation has been the most important factor controlling the evolution of the foreland basin. However, the influence of the Gardan lineament on sedimentation during the Oligocenelower Miocene (including the Ilam Formation) can also be detected. As mentioned above, thickness variations and stratal patterns (Figures 8(a)-(c)) indicate that the basin deepened both east- and westwards away from the Gardan lineament. Thus, the lineament appears to have controlled sedimentation in Santonian time especially in the southern part of the study area. However, its impact at this time apparently decreases northwards, unless its effects are obscured by the superimposed Zagros trend.

\subsection{The Influence of the Zagros Orogeny on Foreland Basin Evolution}

Foreland basins are generally accepted to express downward flexure of the lithosphere in front of a tectonic load 

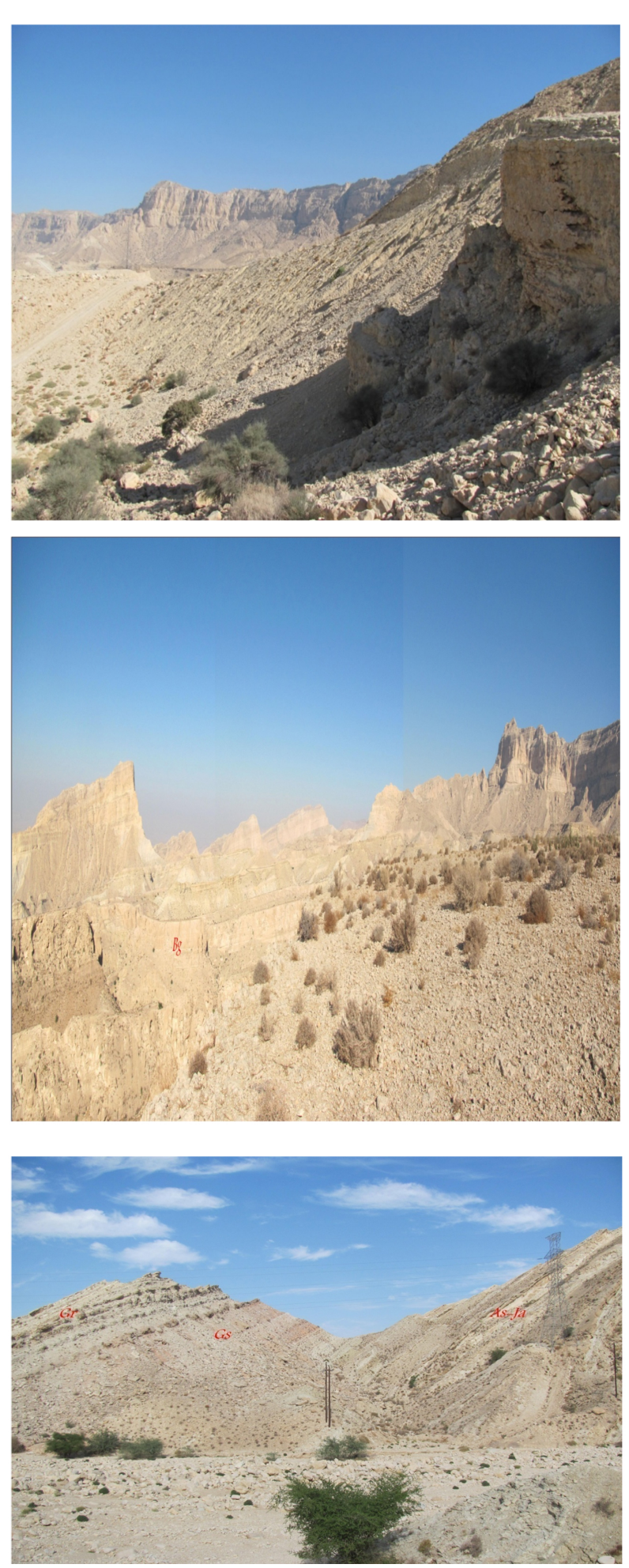

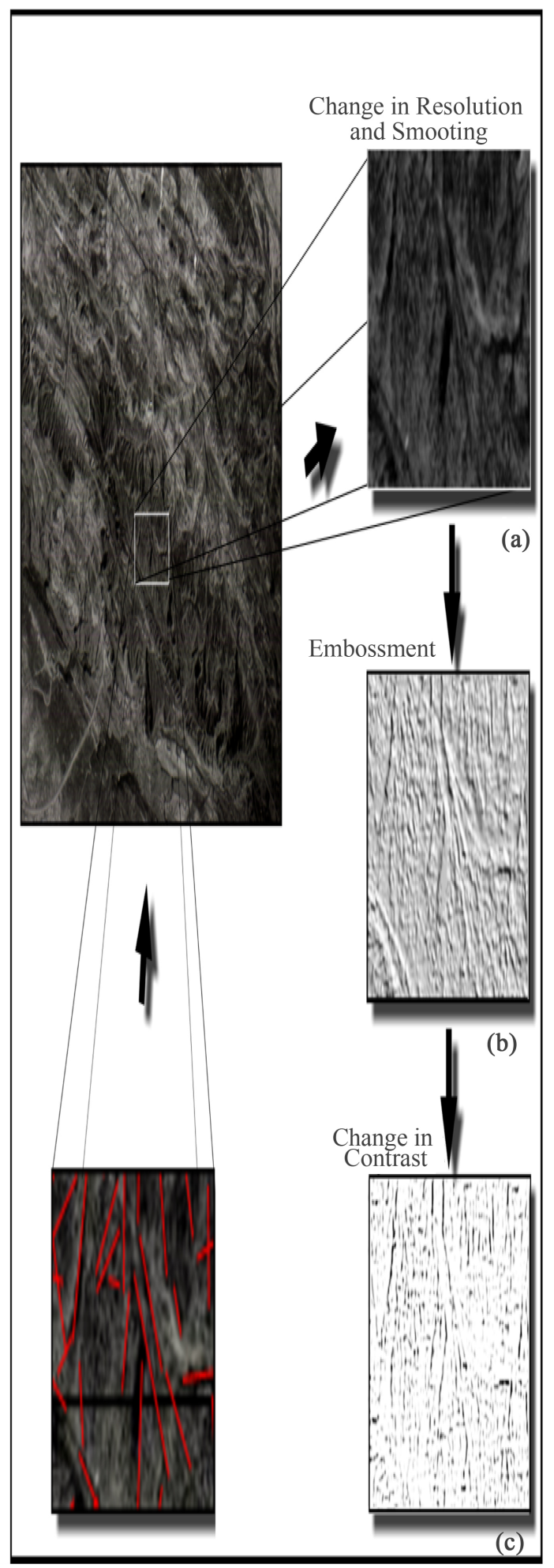

Figure 8. (a) Field photo on the southern limb of the Saiwah anticline, near the eastern side of the Gardan lineament (location in Figure 2). Photo shows SEward progradation of Santonian Ilam Formation carbonates over Coniacian pelagic marls of the Kazhdomi Formation. (b) Field photo on the northern limb of the Saiwah anticline near the eastern margin of the Gardan lineament (location in Figure 2). Photo shows west-to-east thinning of a carbonate reefal package within the Ilam Formation. (c) Field photo on the northern limb of the Homa anticline, to the west of the Gardan lineament (location in Figure 2). Photo shows east-to-west clinoform pattern of carbonate intervals in the Ilam Formation. 
imposed by the advancing thrust sheets [25] [26]. In the Zagros area, evolution of the foreland basin was accelerated by Late Cretaceous ophiolite obduction in the Izeh Zone. A Bouguer anomaly map of Fars (Figure 9) [21] shows that the thickness of the sedimentary cover increases perpendicular to the generally NW-SE Zagros trend from the Mountain Front Fault towards the High Zagros Fault, i.e. from SW to NE. This is a common feature of many foreland basins. Thickness variations in the Zagros fold-and-thrust belt during specific time intervals (Campanian-Maastrichtian, Paleocene-Eocene and Oligocene-early Miocene) indicate that the advancing orogenic wedge resulted in downward flexure of successively more external portions of the foreland, and caused the fore-bulge and the depocentre to migrate to more external parts of the foreland. Therefore, locations which were originally far from the advancing orogenic load may have been uplifted before subsiding as a result of the approach of the orogenic wedge. One piece of evidence which is consistent with foreland basin migration in the study area is the presence of a relatively low-angle unconformity between the Kazhdomi and Ilam Formations some $45 \mathrm{~km}$ SE of Ilam City (Figure 10). This is similar to the unconformity reported by [4] some $40 \mathrm{~km}$ north of Izeh, which was interpreted to indicate uplift of the Kazhdomi Formation, and its exposure to surface erosion, before deposition of the Ilam limestone. Successive isopach maps show (Figure 7).

SW ward migration of the foreland basin depocentre between the Campanian and the early Miocene. In order to trace the effects of the Zagros orogeny on basin evolution, a graph of geological time versus depocentre location was prepared (Figure 11) (the best-fit line through the depocentres is marked as a dashed line on the isopach maps). Using the Campanian-Maastrichtian isopach map as a reference. The orthogonal distance between successive best-fit lines was considered to indicate the amount of depocentre migration towards the SW from the end-Maastrichtian to the end-early Miocene). The graph shows that about $40 \mathrm{~km}$ of SWward depocentre migration took place at a rate of about $1 \mathrm{~km} /$ Ma between $66 \mathrm{Ma}$ and $34 \mathrm{Ma}$ (Albian-Santonian). From 34 to $16 \mathrm{Ma}$ (Mastrichtian), the depocentre migrated some $26 \mathrm{~km}$ to the SW at a faster rate of $1.45 \mathrm{~km} / \mathrm{Ma}$. Thus there was an increase in the rate of the depocentre migration towards the SW in the Santonian-Campanian compared to the Mastrichtian. The reasons for this change in the rate of depocenter migration remain speculative and are not discussed here.

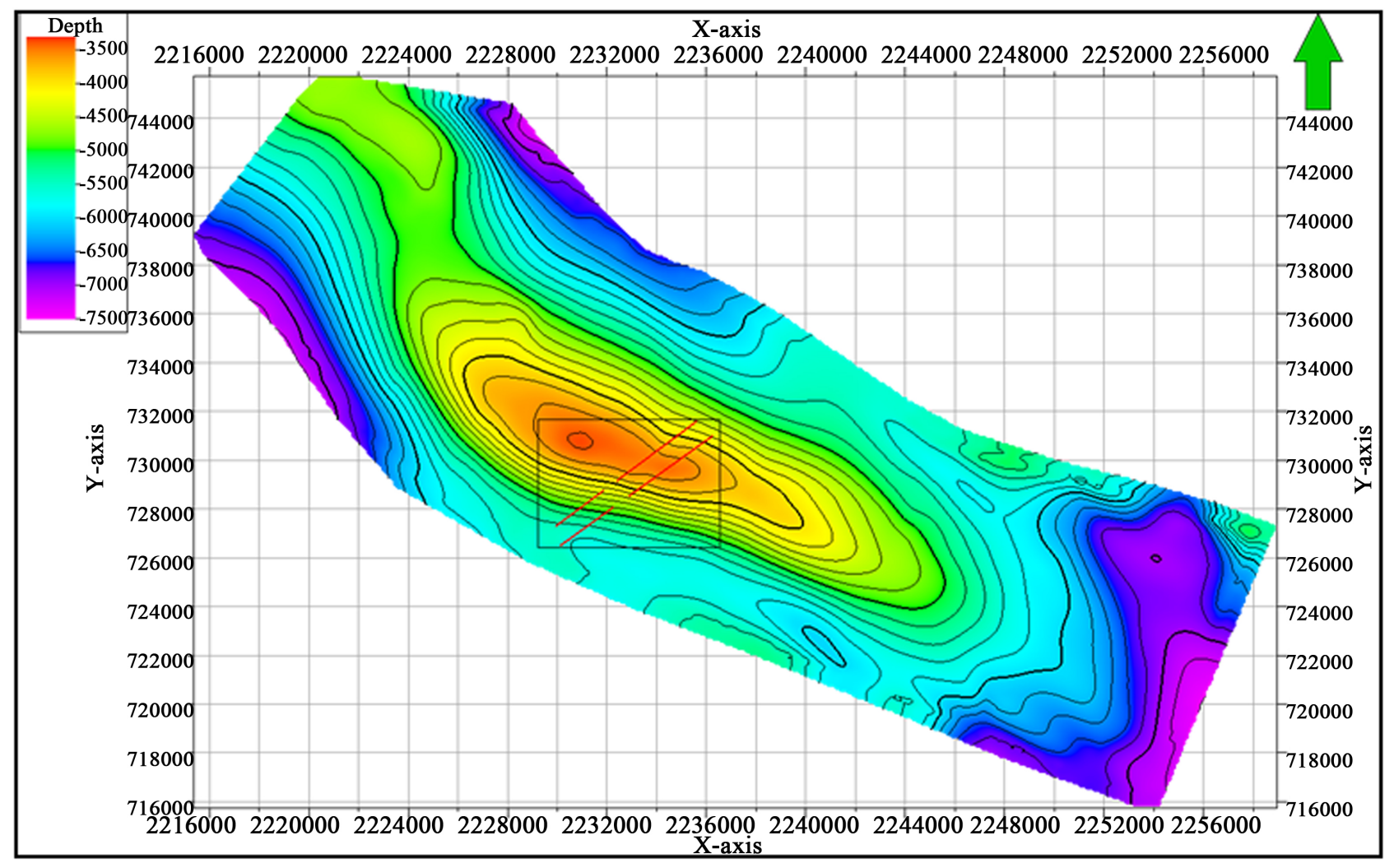

Figure 9. Bouguer anomaly map of the study area with a $20 \mathrm{~km}$ low pass filter. The map shows NW-SE thickening of the sedimentary cover in the Fars foreland basin, at high angle to the general Zagros trend. 

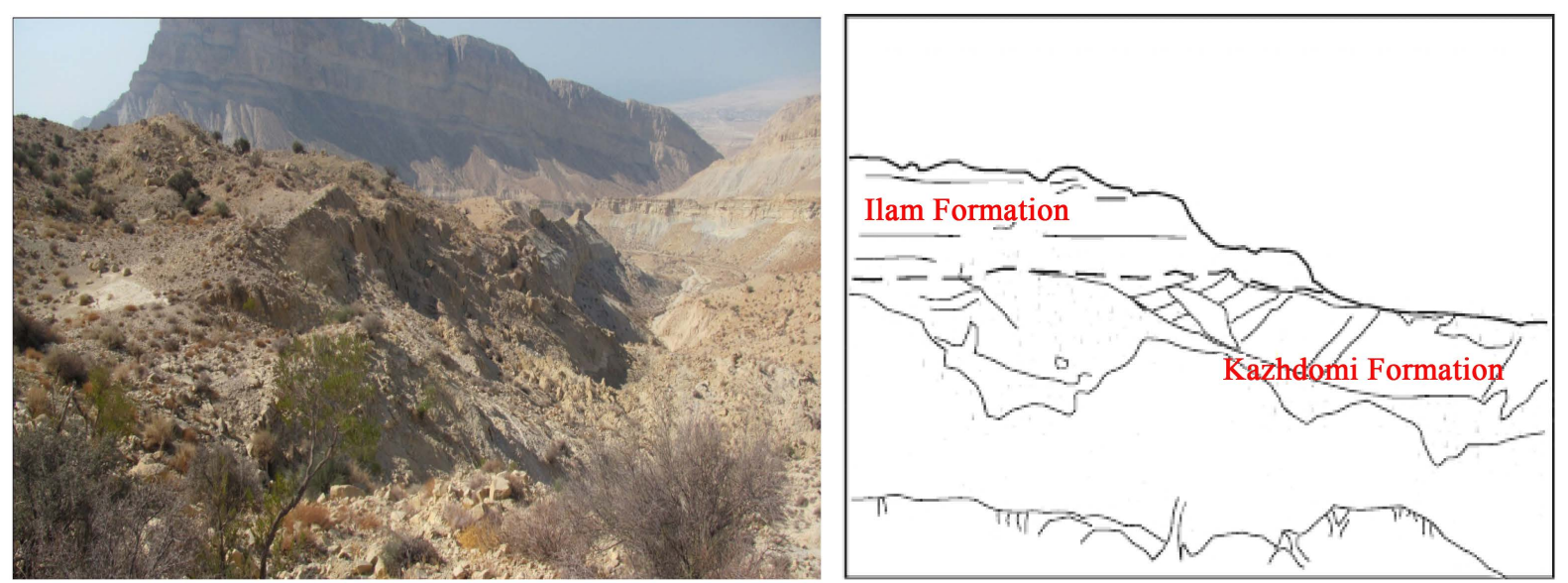

Figure 10. Field photograph and line drawing interpretation, $45 \mathrm{~km} \mathrm{SE}$ of Ilam City (location in Figure 2). Cliffs are about $150 \mathrm{~m}$ high. Note the angular unconformity between the marl-dominated Kazhdomi Formation (Albian) and the Ilam Limestone (Santonian).

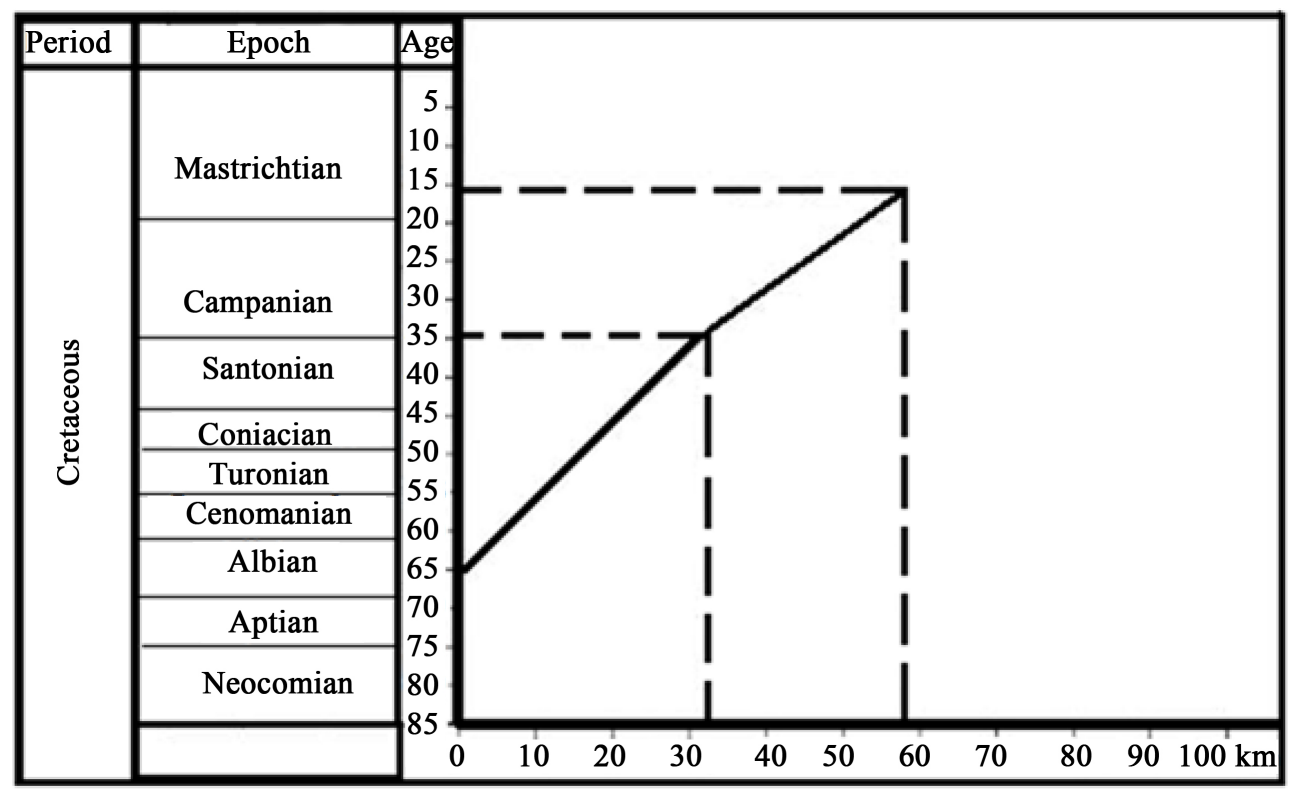

Figure 11. Graph showing migration of the Zagros foreland basin depocentre to the SW between the Maastrichtian. The horizontal axis shows orthogonal distance (in $\mathrm{km}$ ) between the heavy dashed lines on the isopach maps relative to the Campanian-Maastrichtian isopach map.

\subsection{Relative Active Tectonics of the Zagros Orogenic Belt}

The study area is situated in Zagros fold and thrust belt [27]-[34] (Figure 1). From tectonics view, it contains orogenic belt of Arabian plate [35]-[37]. Based on previous work on the salt and mud diapirism [38]-[49] and neotectonic regime in Iran [50]-[55], Zagros is the most active zone [56]-[78]. Then, Alborz [79]-[120] and Central Iran [121]-[138] have been situated in the next orders. Therefore, active tectonics have got an important rule on the rate of fractures on Ilam Formation in the study area.

\section{Conclusion}

The analysis of the basin depocentre between Late Cretaceous obduction and the Santonian indicates progressive SWward migration of the depocentre at different rates during the Zagros orogeny, and documents the evolution of a typical foreland basin in the Fars area. During deposition of the Santonian Ilam and Ilam Formations 
in southern Fars, the architecture of the foreland basin was influenced by the deep-seated, approximately northsouth trending Gardan lineament. During the Santonian to Campanian time interval, this lineament was reactivated to form a palaeohigh in the southern part of the study area. This paleohigh caused facies and thickness changes in the Ilam Formations. Facies changes in the Ilam Formation may explain the observed variations in reservoir quality in the Fars region.

\section{Acknowledgements}

This study was conducted as a part of Ph.D. degree granted by Islamic Azad University, North Tehran Branch.

\section{References}

[1] Versfelt Jr., P.L. (2001) Major Hydrocarbon Potential in Iran. American Association of Petroleum Geologist Memoir, 74, 417-427.

[2] Berberian, M. and King, G.C.P. (1981) Towards the Paleogeography and Tectonic Evolution of Iran. Canadian Journal of Earth Sciences, 18, 210-265. http://dx.doi.org/10.1139/e81-019

[3] Bahroudi, A., and Talbot, C.J. (2003) The Configuration of Basement Beneath the Zagros Basin. Journal of Petroleum Geology, 26, 257.

[4] Hessami, K, Koyi, H., Talbot, C.J. and Shabanian, E. (2001) Progressive Unconformities within an Evolving Foreland Fold-Thrust Belt, Zagros Mountains. Journal of the Geological Society, 158, 969-981. http://dx.doi.org/10.1144/0016-764901-007

[5] Haynes, S.J. and Mcquillan, H. (1974) Evolution of the Zagros Suture Zone, Southern Iran. Geological Society of America Bulletin, 85, 739-744. http://dx.doi.org/10.1130/0016-7606(1974)85<739:EOTZSZ>2.0.CO;2

[6] Nilforoushan, F., Masson, F., Vernant, P., Martinod, J., Abbassi, M., Nankali, H., et al. (2003) GPS Network Monitors the Arabia-Eurasia Collision Deformation in Iran. Journal of Geodesy, 77, 411-422. http://dx.doi.org/10.1007/s00190-003-0326-5

[7] Homke, S., Vergés, J., Garcés, M., Emami, H. and Karpuz, R. (2004) Magnetostratigraphy of Miocene-Pliocene Zagros Foreland Deposits in the Front of the Push-e Kuh Arc (Fars Province, Iran). Earth and Planetary Science Letters, 225, 397-410. http://dx.doi.org/10.1016/j.epsl.2004.07.002

[8] Sengor, A.M.C. (1984) The Cimmeride Orogenic System and the Tectonics of Eurasia. Geological Society of America Special Paper, 195, 1-82.

[9] Falcon, N.L. (1974) Southern Iran: Zagros Mountains. In: Spencer, A., Ed., Mesozoic-Cenozoic Orogenic Belts, Geological Society of London, Special Publication, Vol. 4, 199-211.

[10] Alavi, M. (2004) Regional Stratigraphy of the Zagros Fold-Thrust Belt of Iran and Its Proforeland Evolution. American Journal of Science, 304, 1-20. http://dx.doi.org/10.2475/ajs.304.1.1

[11] Vita-Finzi, C. (2001) Neotectonics at the Arabian Plate Margins. Journal of Structural Geology, 23, 521-530. http://dx.doi.org/10.1016/S0191-8141(00)00117-6

[12] Sella, G.F., Dixon, H. and Mao, A. (2002) A Model for Recent Plate Velocities from Space Geodesy. Journal of Geophysical Research, 107, 11.1-11.30.

[13] Hessami, K., Nilforoushan, F. and Talbot, C.J. (2006) Active Deformation within the Zagros Mountain Deduced from GPS Measurements. Journal of the Geological Society London, 163, 143-148. http://dx.doi.org/10.1144/0016-764905-031

[14] Jackson, J. and McKenzie, D.P. (1988) The Relationship between Plate Motions and Seismic Moment Tensors, and the Rates of Active Deformation in the Mediterranean and Middle East. Geophysical Journal, 93, 45-73. http://dx.doi.org/10.1111/j.1365-246X.1988.tb01387.x

[15] Chandra, U. (1984) Focal Mechanism Solution for Earthquakes in Iran. Physics of the Earth and Planetary Interiors, 34, 9-16. http://dx.doi.org/10.1016/0031-9201(84)90080-3

[16] Alavi, M. (1994) Tectonics of the Zagros Orogenic Belt of Iran: New Data and Interpretations. Tectonophysics, 229, 211-238. http://dx.doi.org/10.1016/0040-1951(94)90030-2

[17] Furst, M. (1990) Strike-Slip Faults and Diapirism of the South Eastern Zagros Ranges. Proceedings of Symposium on Diapirism, Vol. 2, Bandar Abbas, 8-14 December 1990, 149-183.

[18] Berberian, M. (1995) Master Blind Thrust Faults Hidden under the Zagros Folds: Active Basement Tectonics and Surface Morphotectonics. Tectonophysics, 241, 193-224. http://dx.doi.org/10.1016/0040-1951(94)00185-C

[19] Blanc, E.J.-P., Allen, M.B., Inger, S. and Hassani, H. (2003) Structural Style in the Zagros Simple Folded Zone, Iran. Journal of the Geological Society of London, 160, 401-412. http://dx.doi.org/10.1144/0016-764902-110 
[20] McQuillan, H. (1991) The Role of Basement Tectonics in the Control of Sedimentary Facies, Structural Patterns and Salt Plug Emplacement in the Zagros Fold Belt of Southwest Iran. Journal of Southeast Asian Earth Sciences, 5, 453463. http://dx.doi.org/10.1016/0743-9547(91)90061-2

[21] Tabatabayi, M. (2005) Reinterpretation of Gravity Data in Fars- Internal Report. Exploration Directorate of National Iranian Oil Company. (Unpublished)

[22] Ameen, M.S. (1992) Effect of Basement Tectonics on Hydrocarbon Generation, Migration and Accumulation in Northern Iraq. AAPG Bulletin, 76, 356-370.

[23] Hessami, K.H.A. and Talbot, C.J. (2001) The Significance of Strike-Slip Faulting in the Basement of the Zagros Fold-Thrust Belt. Journal of Petroleum Geology, 24, 5-28. http://dx.doi.org/10.1111/j.1747-5457.2001.tb00659.x

[24] Barzegar, F. (1994) Basement Fault Mapping of E Zagros Folded Belt (SW Iran) Based On Space-Born Remotely Sensed Data. Proceeding of the 10th Thematic Conference on Geologic Remote Sensing: Exploration, Environment, and Engineering, Vol. 1, San Antonio, 9-12 May 1994, 455-466.

[25] Flemings, P.B. and Jordan, T. (1989) A Synthetic Stratigraphic Model of Foreland Basin Development. Journal of Geophysical Research, 94, 3851- 3866. http://dx.doi.org/10.1029/JB094iB04p03851

[26] Price, R.A. (1973) Large Scale Gravitational Flow of Supra-Crustal Rocks, Southern Canadian Rockies. In: De Jong, K.A. and Scholten, K., Eds, Gravity and Tectonics, John Wiley, New York, 491-502.

[27] Khodabakhshnezhad, A. and Arian, M. (2016) Salt Tectonics in the Southern Iran. International Journal of Geosciences, 7, 367-377. http://dx.doi.org/10.4236/ijg.2016.73029

[28] Abdolizadeh, S., Maleki, Z. and Arian, M. (2016) Earthquake Hazard Zonation and Seismotectonics of the Bandar Abbas Area, Zagros, Iran. Open Journal of Geology, 6, 210-224. http://dx.doi.org/10.4236/ojg.2016.63019

[29] Arian, M. (2010) Tectonics and Sedimentation. Farazamin Press, Tehran, 307 p.

[30] Arian, M. and Maleki, Z. (2010) Principals of Experimental Tectonics. Asar Nafis Publication, Qum, 224 p.

[31] Hadizadeh, A., Arian, M. and Ganjouyan, M.A. (2011) Analysis Geometry Dashtak Detachment Zone in the Dashtak, Salamati and Sepidar Anticlines from Interior and Sub Coastal Fars Area. Journal of the Earth, 6, 33-44.

[32] Khodabakhshnezhad, A., Arian, M. and Pourkermani, M. (2008) The Elements of Fold Style Analysis in the Asmari Anticline (Zagros). Journal of Sciences, 18, 129-138.

[33] Khodabakhshnezhad, A., Arian, M. and Pourkermani, M. (2015) Folding Mechanism in the Asmari Anticline, Zagros, Iran. Open Journal of Geology, 5, 197-208. http://dx.doi.org/10.4236/ojg.2015.54018

[34] Arian, M., Pourkermani, M., Khodabakhshnezhad, A. and Noroozpour, H. (2011) Investigation of Oil Trap in the Asmari Anticline (Zagros, Iran). Indian Journal of Science and Technology, 4, 1696-1699.

[35] Arian, M. (2013) Physiographic-Tectonic Zoning of Iran’s Sedimentary Basins. Open Journal of Geology, 3, $169-177$. http://dx.doi.org/10.4236/ojg.2013.33020

[36] Qorashi, M. and Arian, M. (2011) Tectonics of Iran. Geologic Survey of Iran, Tehran, 336 p.

[37] Arian, M. (2011) Basement Tectonics and Geology of Iran. Asar Nafis Press, Qum, 300 p.

[38] Arian, M. (2011) A Preface on Salt Diapirism of Iran. Asar Nafis Press, Qum, 309 p.

[39] Arian, M. and Noroozpour, H. (2015) The Biggest Salt-Tongue Canopy of Central Iran. Open Journal of Geology, 5, 55-60. http://dx.doi.org/10.4236/ojg.2015.52005

[40] Asadian, F., Pourkermani, M. and Arian, M. (2007) Tectonic Geomorphology of Salt Structures in the GarmsarLasjerd Area. Geographical Research, 39, 75-84.

[41] Pourkermani, M. and Arian, M. (1997) Salt Domes of Central Iran. Journal of Humanities, 3, 29-41.

[42] Arian, M. (2012) Salt Diapirism and Tectonics. 2nd Edition, Asar Nafis Press, Qum, 319 p.

[43] Arian, M. and Noroozpour, H. (2015) Tectonic Geomorphology of Iran’s Salt Structures. Open Journal of Geology, 5, 61-72. http://dx.doi.org/10.4236/ojg.2015.52006

[44] Asadian, F. and Arian, M. (2009) Identification of Diapiric Provinces of Central Iran through Geological and Geographical Analysis. International Journal of Agriculture Environment \& Biotechnology, 2, 3443-3451.

[45] Arian, M. (2012) Clustering of Diapiric Provinces in the Central Iran Basin. Carbonates and Evaporites, 27, 9-18. http://dx.doi.org/10.1007/s13146-011-0079-9

[46] Pourkermani, M. and Arian, M. (1998) Tectonic Geomorphology of Salt Domes in West of Zanjan Province, Iran. Geographical Research, 47, 44-53.

[47] Arian, M. and Feizi, F. (2010) The Significance of Faulting on the Surficial Spreading of Evaporitic Deposits in the Varamin-Semnan Area. Journal of Earth and Resources, 3, 1-20. 
[48] Feizi, F., Arian, M. and Arian, A. (2015) Mud Diapirism on the Makran, Iran: Case Study on the Napag Mud Volcano. Open Journal of Geology, 5, 300-308. http://dx.doi.org/10.4236/ojg.2015.55027

[49] Arian, M. and Sistanipour, A. (2015) Mud Diapirism on the Gorgan. North Iran Open Journal of Geology, 5, $442-450$. http://dx.doi.org/10.4236/ojg.2015.56041

[50] Arian, M. and Khodabakhshnezhad, A. (2015) Sedimentary Environments Can Be Changed by Geotechnology (Case Study: A Morphotectonic Idea for Design of Extensive Artificial Bay on the Iranian Plateau). International Journal of Geosciences, 6, 487-496. http://dx.doi.org/10.4236/ijg.2015.65039

[51] Arian, M. (2011) Middle East Tectonics. Asar Nafis Press, Qum, 236 p.

[52] Arian, M. (2010) Applied Seismotectonics. Farazamin Press, Tehran, 304 p.

[53] Arian, M. and Maleki, R. (2008) Neotectonics. Farazamin Research Center, Tehran, 150.

[54] Pourkermani, M. and Arian, M. (1998) Seismicity of Iran. Shahid Beheshti University Press, Tehran, 212.

[55] Pourkermani, M. and Arian, M. (1997) Seismotectonics. DezAb Consulting Engineers Company Press, Tehran, 270.

[56] Arian, M. and Aram, Z. (2014) Relative Tectonic Activity Classification in the Kermanshah Area, Western Iran. Solid Earth, 5, 1277-1291. http://dx.doi.org/10.5194/se-5-1277-2014

[57] Mashal, M., PourKermani, M., Charchi, A., Almasian, M. and Arian, M. (2013) Pattern of Structural Geology Underground in Eastern of North Dezfol Embayment. Advances in Environmental Biology, 7, 260-268.

[58] Pazhoohan, M., Arian, M., Ghorashi, M. and Khosrotehrani, K. (2014) A Study of Drainage Pattern Responses to Active Tectonics in Tadvan Region, SW Iran. Geodynamics, 1, 36-41.

[59] Rahimi, N. and Arian, M. (2014) Tectonic Geomorphplogy of Kangavar-Sosangerd Region, West Iran. Advances in Environmental Biology, 8, 119-124.

[60] Arian, M. and Hashemi, A. (2008) Seismotectonic Zoning in the Zagros. Journal of Sciences, 18, 63-76.

[61] Arian, M., Ahmadnia, A., Qorashi, M. and Pourkermani, M. (2002) Structural Analysis of Mengharak Transcurrent Fault System in Zagros, Iran. Special GEO 2002 Conference Issue Geoarabia, 7, 209-210.

[62] Arian, M., Qorashi, M. Pourkermani, M. and Ahmadnia, A. (2003) Fractal Analysis of Mengharak Transcurrent Fault System in Zagros, Iran. Proceedings of the Fourth International Conference on Seismology and Earthquake Engineering, Tehran, 12-14 May 2003, 23.

[63] Baharvand, S., Pourkermani, M., Ajalloian, R., Arian, M. and Nouryazdan, A.R. (2010) Seymareh Landslide and Its Role in Environmental and Geomorphologic Changes of the Pole-Dokhtar Area. Journal of the Earth, 4, 13-24.

[64] Abdideh, M., Qorashi, M., Rangzan, K. and Arian, M. (2011) Assessment of Relative Active Tectonics Using Morphometric Analysis, Case Study of Dez River (Southwestern, Iran). Geosciences, 20, 33-46.

[65] Arian, M., Qorashi, M., Pourkermani, M. and Ahmadnia, A. (2006) The Structural Significance Kareh Bas Transcurrent Fault System in the Zagros Fold and Thrust Belt. Geosciences, 15, 126-133.

[66] Arian, M. and Noroozpour, H. (2015) Seismic Activity and Fractal Geometry of Kareh Bas Fault System in Zagros, South of Iran. Open Journal of Geology, 5, 291-299. http://dx.doi.org/10.4236/ojg.2015.55026

[67] Ehsani, J. and Arian, M. (2015) Quantitative Analysis of Relative Tectonic Activity in the Jarahi-Hendijan Basin Area, Zagros Iran. Geosciences Journal, 19, 1-15. http://dx.doi.org/10.1007/s12303-015-0016-3

[68] Omidali, M., Arian, M. and Sorbi, A. (2015) Neotectonics of Boroujerd Area, SW Iran by Index of Active Tectonics. Open Journal of Geology, 5, 309-324. http://dx.doi.org/10.4236/ojg.2015.55028

[69] Chegini, A., Sorbi, A. and Arian, M. (2015) Active Tectonics of Hamedan Area, SW Iran by Index of Active Tectonics. International Journal of Geology, 4, 108-118.

[70] Maleki, Z., Arian, M., Solgi, A. and Ganjavian, M.A. (2014) The Elements of Fold Style Analysis in the Khaftar Anticline, Zagros, Iran. Open Journal of Geology, 4, 79-92. http://dx.doi.org/10.4236/ojg.2014.43008

[71] Maleki, Z., Arian, M. and Solgi, A. (2014) Structural Style and Hydrocarbon Trap of Karbasi Anticline, in the Interior Fars Region, Zagros, Iran. Solid Earth Discussions, 6, 2143-2167. http://dx.doi.org/10.5194/sed-6-2143-2014

[72] Ehsani, J., Arian, M. and Ghorashi, M. (2015) Geomorphic Signatures of Active Tectonics in the Jarahi-Hendijan Drainage Basin in the South West Iran. Geosciences, 24, 211-218.

[73] Khodabakhshnezhad, A., Pourkermani, M., Arian, M., Matkan, A.A. and Charchi, A. (2015) Active Tectonics of Great Karounriver Basin. Geosciences, 24, 13-28.

[74] Maleki, Z., Arian, M., Solgi, A. and Ganjavian, M.A. (2015) Elements of Fold Style Analysis in the Karbasi Anticline, Interior Fars Region, Zagros. Geosciences, 24, 293-302.

[75] Baratpour, F., Arian, M. and Solgi, A. (2015) Geometric Analysis of Tukak and Kamarun Anticlines on Izeh Zone, Zagros. Geosciences, 24, 191-200. 
[76] GholamhoseinFard, N., Sorbi, A. and Arian, M. (2015) Active Tectonics of Kangavar Area, West Iran. Open Journal of Geology, 5, 422-441. http://dx.doi.org/10.4236/ojg.2015.56040

[77] Maleki, Z., Arian, M. and Solgi, A. (2015) Folding Pattern in the Fars Province, Zagros Folded Belt: Case Study on the Karbasi and Khaftar Anticlines, Interior Fars, Iran. Solid Earth Discussions, 7, 2347-2379. http://dx.doi.org/10.5194/sed-7-2347-2015

[78] Aram, Z. and Arian, M. (2016) Active Tectonics of the Gharasu River Basin in Zagros, Iran, Investigated by Calculation of Geomorphic Indices and Group Decision Using Analytic Hierarchy Process (AHP) Software. Episodes, 39, 3944. http://dx.doi.org/10.18814/epiiugs/2016/v39i1/89235

[79] Alladin, Y., Talebian, M., Arian, M. and Ahmadi, M.M. (2015) Geotechnical Investigation and Seismic Zonation of Alluvial Deposits in Western Tehran. Geosciences, 24, 333-342.

[80] Taherkhani, B., Nazari, H., Pourkermani, M. and Arian, M. (2015) Geometry and Recent Kinematics of the North Qazvin Fault: Morphotectonic Approach. Geosciences, 24, 29-38.

[81] Manuchehri, H., Arian, M., Ghorashi, M., Solgi, M. and Sorbi, A. (2015) Geomorphic Signatures of Active Tectonics in the Chalus Drainage Basin in the Alborz, Iran. Geosciences, 24, 273-280.

[82] Noroozpour, H., Arian, M. and Sorbi, A. (2015) Fault Movement Potentials in the Tehran-Semnan Region (North Iran). Open Journal of Geology, 5, 281-290. http://dx.doi.org/10.4236/ojg.2015.55025

[83] Arian, M., Maleki, Z. and Noroozpour, H. (2011) Cenozoic Diastrophism and Deformational Events in the East Central Alborz. Journal of Basic and Applied Scientific Research, 1, 2394-2400.

[84] Feizi, F., Arian, A. and Rahmani, R. (2007) Seismotectonic Zoning in the Eastern Part of the Central Alborz. Journal of Sciences, 17, 151-164.

[85] Khavari, R., Arian, M. and Ghorashi, M. (2009) Neotectonics of the South Central Alborz Drainage Basin, in NW Tehran, N Iran. Journal of Applied Sciences, 9, 4115-4126. http://dx.doi.org/10.3923/jas.2009.4115.4126

[86] Arian, M. and Bagha, N. (2012) Active Tectonics of Tehran Area, Iran. Journal of Basic and Applied Scientific Research, 2, 3805-3819.

[87] Bagha, N., Arian, M., Ghorashi, M., Pourkermani, M., El Hamdouni, R. and Solgi, A. (2014) Evaluation of Relative Tectonic Activity in the Tehran Basin, Central Alborz, Northern Iran. Geomorphology, 213, 66-87. http://dx.doi.org/10.1016/j.geomorph.2013.12.041

[88] Arian, M. and Feizi, F. (2005) Application of Geomorphic Indices to the Assessment of Relative Tectonic Activity Levels in the Alborz-Central Iran Border Zone. Journal of Sciences, 15, 378-403.

[89] Arian, M., Bagha, N., Khavari, R. and Noroozpour, H. (2012) Seismic Sources and Neo-Tectonics of Tehran Area (North Iran). Indian Journal of Science and Technology, 5, 2379-2383.

[90] Moghimi, H., Arian, M. and Sorbi, A. (2015) Fault Movement Potential of Marzanabad Area, North Alborz, Iran. Open Journal of Geology, 5, 126-135. http://dx.doi.org/10.4236/ojg.2015.53012

[91] Arian, M. and Pourkermani, M. (2004) Tectonic Elements of South Flank in the East-Central Alborz Mountain. Journal of Sciences, Teacher Training University, 4, 359-368.

[92] Arian, M. and Qorashi, M. (2006) The Movement Potential Evaluation of the Major Quaternary Faults in AlborzCentral Iran Border Zone, from the East of Tehran to the East of Semnan. Journal of Geosciences, Geological Survey of Iran, 15, 184-188.

[93] Poroohan, N., Pourkermani, M. and Arian, M. (2013) An Assessment of Relationship in F-Parameter and Paleostress Fields in Heterogeneous Lithologies: Roudbar Area (Northwest of Iran). Australian Journal of Basic \& Applied Sciences, 7, 933-942.

[94] Poroohan, N., Poukermani, M. and Arian, M. (2009) An Assessment on Correlations of Seismotectonic Parameters Preceding and Following Roudbar-Manjil Earthquake (Gilan, North of Iran). Australian Journal of Basic \& Applied Sciences, 3, 2643-2652.

[95] Farrokhnia, A.R., Pirasteh, S., Pourkermani, M. and Arian, M. (2011) Geo-Information Technology for Mass Wasting Hazard Zonation: Central-West Alborz-Iran. Disaster Advances, 4, 24-33.

[96] Khavari, R., Ghorashi, M. and Arian, M. (2009) Assessment of Relative Active Tectonics, South Central Alborz (North Iran). EGU General Assembly Conference Abstracts, 11, 1137.

[97] Sorbi, A., Arian, M. and Pourkermani, M. (2009) The Movement Potential Evaluation of the Major Quaternary Faults in Tehran Quadrangle. Journal of the Earth, 19, 176-182.

[98] Feizi, F. and Arian, M. (2006) The Classification of Thrust Fronts in the Alborz-Central Iran Border Zone from the East of Varamin to the East of Semnan. Journal of Sciences, 16, 75-87.

[99] Khosroshahizadeh, S., Pourkermani, M., Almasian, M., Arian, M. and Khakzad, A. (2016) Lineament Patterns and 
Mineralization Related to Alteration Zone by Using ASAR-ASTER Imagery in Hize Jan-Sharaf Abad Au-Ag Epithermal Mineralized Zone (East Azarbaijan-NW Iran). Open Journal of Geology, 6, 232-250. http://dx.doi.org/10.4236/ojg.2016.64021

[100] Arian, M. and Pourkermani, M. (2004) Structural Significance of North Semnan and Attary Faults in Alborz-Central Iran Border Zone. Journal of Science, 14, 4551-4569.

[101] Arian, M. and Pourkermani, M. (2005) Cenozoic Diastrophism and Deformational Events in the Southern Flank of Central-East Alborz. Journal of Faculty Earth Sciences, 10, 43-51.

[102] Sadeghi, R., Saeedi, A., Arian, M., Ghorashi, M. and Solgi, A. (2015) Comparison of Strain Ellipsoid Shape in the South of Ardabil Range (NW), Based on the Results of the Magnetic Susceptibility Anisotropy and Paleostress Methods. Open Journal of Geology, 5, 611-622. http://dx.doi.org/10.4236/ojg.2015.59054

[103] Arian, M., Pourkermani, M., Qorashi, M. and Ghasemi, M.R. (2003) North Semnan Fault System and Its Role on Basin Division. Proceedings of the 8th Symposium of Geological Society of Iran, Shahrood, 4-6 September 2003, 11-17.

[104] Pourkermani, M. and Arian, M. (2001) Structural Geomorphology of Northeastern Kurdistan. Journal of Humanities, 7 , 37-48.

[105] Mardani, Z., Ghorashi, M. and Arian, M. (2011) Geomorphic Signatures of Active Tectonics in the Talaghanrud, Shahrudand Sefidrud Drainage Basins in Central Alborz, N Iran. Geosciences, 20, 159-166.

[106] Sorbi, A., Arian, M. and Pourkermani, M. (2011) The Application of Geomorphic Indices to the Assessment of Relative Tectonic Activity Levels in Tehran Quadrangle. Journal of the Earth, 6, 1-9.

[107] Khavari, R., Ghorashi, M., Arian, M. and Khosrotehrani, K. (2010) Geomorphic Signatures of Active Tectonics in the Karaj Drainage Basin in South Central Alborz, N Iran. Geosciences, 19, 67-74.

[108] Mousavi, E.J. and Arian, M. (2015) Tectonic Geomorphology of Atrak River, NE Iran. Open Journal of Geology, 5, 106-114. http://dx.doi.org/10.4236/ojg.2015.53010

[109] Nouri, R., Jafari, M.R., Arian, M., Feizi, F. and Afzal, P. (2013) Correlation between Cu Mineralization and Major Faults Using Multifractal Modelling in the Tarom Area (NW Iran). Geologica Carpathica, 64, 409-416. http://dx.doi.org/10.2478/geoca-2013-0028

[110] Nouri, R., Jafari, M.R., Arian, M., Feizi, F. and Afzal, P. (2013) Prospection for Copper Mineralization with Contribution of Remote Sensing, Geochemical and Mineralographical Data in Abhar 1:100,000 Sheet, NW Iran. Archives of Mining Sciences, 58, 1071-1084. http://dx.doi.org/10.2478/amsc-2013-0074

[111] Nouri, R., Afzal, P., Arian, M., Jafari, M. and Feizi, F. (2013) Reconnaissance of Copper and Gold Mineralization Using Analytical Hierarchy Process in the Rudbar 1:100,000 Map Sheet, Northwest Iran. Journal of Mining and Metallurgy, 49, 9-19.

[112] Farrokhnia, A.R., Pirasteh, S., Pradhan, B., Pourkermani, M. and Arian, M. (2011) A Recent Scenario of Mass Wasting and Its Impact on the Transportation in Alborz Mountains, Iran Using Geo-Information Technology. Arabian Journal of Geosciences, 4, 1337-1349. http://dx.doi.org/10.1007/s12517-010-0238-7

[113] Arian, M. and Nouri, R. (2015) Lineament Tectonics and Mineralization in Tarom Area, North Iran. Open Journal of Geology, 5, 115-124. http://dx.doi.org/10.4236/ojg.2015.53011

[114] Feizi, F. and Arian, M. (2011) The Role of Structural Controllers in Geneses of Copper Deposits in 1:50000 Map of Saiin Qaleh. Journal of Sciences, 21, 1-10.

[115] Arian, M., Qorashi, M. and Ahmadnia, A. (2003) Analysis of Behbahan Shear Zone. Iranian journal of Geology, 1, 1-4.

[116] Bahiraee, S., Arian, M., Qorashi, M. and Solgi, M. (2015) The Movement Potential Evaluation of the Mosha Fault (The West of Firoozkuh to the Shahrestanak). Geosciences, 24, 123-126.

[117] Bagha, N., Ghorashi, M., Arian, M., Pourkermani, M. and Solgi, A. (2015) Neotectonic Analysis of Mosha-North Tehran Fault Zone, Based on Morphotectonic Features, Central Alborz, Northern Iran. Geosciences, 24, 41-52.

[118] Mosavi, E. and Arian, M. (2015) Neotectonics of Kashaf Rud River, NE Iran by Modified Index of Active Tectonics (MIAT). International Journal of Geosciences, 6, 776-794. http://dx.doi.org/10.4236/ijg.2015.67063

[119] Nouri, R. and Arian, M. (2015) Structural Control on the Distribution of Hydrothermal Alteration Zones and Mineralization in Dastjerdeh Area Based on Remote Sensing Data, NW Iran. Bulletin of the Georgian National Academy of Sciences, 9, 79-86.

[120] Khosroshahizadeh, S., Pourkermani, M., Almasiyan, M., Arian, M. and Khakzad, A. (2015) Evaluation of Structural Patterns and Related Alteration and Mineralization Zones by Using ASAR-ASTER Imagery in Siyahrood Area (East Azarbaijan-NW Iran). Open Journal of Geology, 5, 589-610. http://dx.doi.org/10.4236/ojg.2015.59053

[121] Sistanipour, A. and Arian, M. (2015) Geometric Analysis of Davaran Fault System, Central Iran. Open Journal of Geology, 5, 458-469. http://dx.doi.org/10.4236/ojg.2015.56043 
[122] Nazemi, M., Ghorashi, M., Ghassemi, M.R. and Arian, M. (2015) Morphotectonics Features of Alluvial Fans Associated with Active Tectonics (Shotori Mountains, East of Tabas-Central Iran). Geosciences, 24, 91-100.

[123] Alizadeh, H. and Arian, M. (2015) Rule of Structural Factors in Formation of Porphyry Copper Deposits in South Western Part of Kerman Area, Iran. Open Journal of Geology, 5, 489-498. http://dx.doi.org/10.4236/ojg.2015.57045

[124] Mosavi, E.J. and Arian, M. (2015) Neotectonics of Tabas Area, Central Iran by Index of Active Tectonics (IAT). Open Journal of Geology, 5, 209-223. http://dx.doi.org/10.4236/ojg.2015.54019

[125] Daryani, N.J., Arian, M. and Omran, N.R. (2015) Tectonics and Mineralization of Copper in the Ardestan-Kahang Area, Central Iran by Remote Sensing. Open Journal of Geology, 5, 188-196. http://dx.doi.org/10.4236/ojg.2015.54017

[126] Arian, M. and Pourkermani, M. (2001) Rivers Morphology and Active Tectonic (Reviewing the Current Status of Ghezel Ozon River in the Province of Zanjan). Proceedings of the 5th Conference of Geological Society of Iran, Tehran, 28-30 August 2001, 556.

[127] Eshghi, Z., Arian, M. and Pourkermani, M. (2012) Structural Investigation on the Lak Mining Area (Bueen Zahra) Based on Remote Sensing, Used for Its Mineralization. Journal of the Earth, 6, 145-155.

[128] Arian, M., Toudeshki, V.H. and Noroozpour, H. (2011) Active Tectonics of Qezel Ozan River Basin, NW Iran. Journal of Applied Environmental and Biological Sciences, 1, 291-295.

[129] Alizadeh, H., Arian, M., Lotfi, M., Ghorashi, M. and Ghorbani, M. (2015) Determination of Porphyry Copper Deposit Locations Using Photo Lineament Factor in Northern Parts of the Dehaj-Sardoiyeh Belt. Geosciences, 24, $247-252$.

[130] Toudeshki, V.H., Pourkermani, M., Arian, M. and Khosrotehrani, K.H. (2011) Influence of Structures on the Ghezel Ozan River. Geosciences, 21, 55-60.

[131] Toudeshki, V.H. and Arian, M. (2011) Morphotectonic Analysis in the Ghezel Ozan River Basin, NW Iran. Journal of Geography and Geology, 3, 258-260. http://dx.doi.org/10.5539/jgg.v3n1p258

[132] Arian, M. (2015) Seismotectonic-Geologic Hazards Zoning of Iran. Earth Sciences Research Journal, 19, 7-13. http://dx.doi.org/10.15446/esrj.v19n1.40664

[133] Arian, M., Pourkermani, M., Sistanipour, A. and Noroozpour, H. (2011) Kinematic Significance of Fold- and FaultRelated Fracture Systems in the Rafsanjan’s Northeast Highlands (Central Iran). Journal of Basic and Applied Scientific Research, 1, 3398-3406.

[134] Arian, M., Pourkermani, M., Sistanipour, A. and Noroozpour, H. (2011) Seismicity and Fault Segmentation of BafqBaghin Fault System (Central Iran). Journal of Applied Environmental and Biological Sciences, 1, 382-396.

[135] Mosavi, E.J., Arian, M., Ghorashi, M. and Nazemi, M. (2012) Measurements of Geomorphic Indices in Tabas Area. Journal of the Earth, 7, 213-225.

[136] Arian, M. (2010) Earthquake-Fault Hazard Investigations in the Kerman Quadrangle. Journal of Sciences, 19, $176-182$.

[137] Arian, M. and Sorbi, A. (2011) Remote Sensing Investigation of the Faults and Lineaments in the Karaj-Qazvin Region. Journal of the Earth, 5, 21-34.

[138] Arian, M., Alizadeh, H. and Noroozpour, H. (2011) Satellite Geometry of Faults and Fractures and Its Relationship with Porphyry Deposits in Northern Parts of Dahaj-Sardoiyeh Belt, South of Iran. Indian Journal of Science and Technology, 4, 1303-1306.

\section{Submit or recommend next manuscript to SCIRP and we will provide best service for you:}

Accepting pre-submission inquiries through Email, Facebook, Linkedin, Twitter, etc

A wide selection of journals (inclusive of 9 subjects, more than 200 journals)

Providing a 24-hour high-quality service

User-friendly online submission system

Fair and swift peer-review system

Efficient typesetting and proofreading procedure

Display of the result of downloads and visits, as well as the number of cited articles

Maximum dissemination of your research work

Submit your manuscript at: http://papersubmission.scirp.org/ 